\title{
Dietary inclusion of neem leaf powder on growth performance, blood biochemical parameters and profitability of broilers
}

\author{
ME Hossain*, MT Siddiqua1, MM Hossain²
}

Department of Poultry Science, Bangladesh Agricultural University, Mymensingh-2202, ${ }^{1}$ School of Health and Life Sciences, Teesside University, UK, ${ }^{2}$ Department of Animal Resource and Science, Dankook University, South Korea

\begin{abstract}
The experiment was carried out to investigate the effects of neem (Azadirachta indica) leaf powder (NLP) over a period of 35 days on the growth performance, dressing parameters, serum biochemical parameters and profitability of broiler meat. Day old broiler chicks $(n=320)$ were randomly assigned to five dietary groups, each with four replicates. The dietary treatment groups were; control (basal diet; no additives), antibiotic (basal diet + antibiotic), NLP $0.25 \%$ (basal diet $+0.25 \%$ NLP), NLP $0.375 \%$ (basal diet $+0.375 \%$ NLP) and NLP $0.50 \%$ (basal diet $+0.50 \%$ NLP). Results showed that the body weight, body weight gain, feed intake and FCR were differed significantly $(P<0.05)$ among the treatment groups. Body weight and body weight gain were higher in antibiotic, NLP $0.25 \%$ and NLP $0.375 \%$ group compare to the NLP $0.50 \%$ group. Total feed intake was not different significantly $(P>0.05)$. Better $(P<0.05)$ FCR was observed in NLP $0.25 \%$ group as such as antibiotic group compare to the control and NLP $0.50 \%$ group. The results also showed that dressing parameters were not significantly $(P>0.05)$ different among the dietary groups. Serum glucose, triglyceride, GOT, GPT and cholesterol level were non-significant $(P>0.05)$ among the dietary groups. However, HDL was significantly $(P<0.05)$ higher in NLP $0.25 \%$ group compared to the control group. Higher profitability was found in NLP-0.25\% group and antibiotic group when all the birds were sold at market price. It can be concluded that the addition of NLP to broiler diet had a positive effect on growth performances but no negative effect on dressing parameters and serum biochemical parameters. Moreover, NLP at the level of $0.25 \%$ increases HDL level and improve profitability. It can be suggested that neem leaf powder up to $0.375 \%$ could be potential feed additive in broiler diet.
\end{abstract}

Keywords: Neem, growth, blood, profitability, broiler

\section{Introduction}

Broiler industry in Bangladesh has grown dramatically in the past two decades. Numerous researches and breeding programs further enhanced feed utilization, growth rate and profitability. Broiler industry is the most economical and effective converter of grain into animal protein. In broiler farming feed costs is approximately $70 \%$ of total production cost. Also, nutrients lost through feces either undigested or unabsorbed for the intestinal microbial population either by parasitic action or occupation of receptors on the intestinal epithelium could results in economic loss to the farmer (Lu and Walker, 2001). The use of antibiotics in the poultry diet is mainly as growth promoter and prevention of several diseases. However, use of antibiotics in feeds caused development of resistant bacteria which could be transferred from animals to humans (Stanton, 2013). Because of these antibiotic resistant bacteria in animal farm, several countries ban the use of certain antibiotics as growth promoter and feed additive (FAO, 2003). After the ban of antibiotics, poultry industry now needs alternatives to antibiotics growth promoters to keep poultry farming profitable. During finding alternatives to antibiotic feed additives to control diseases as well as increase production efficiency in poultry, scientists tried different types of additive alternative including probiotics, prebiotics, enzymes, organic acids, and medicinal plants (Islam et al., 2012; Hossain et al., 2012; El-Latif et al., 2013; Hossain and Yang, 2014; Hasan et al., 2018; Rashid et al., 2020), which showed encouraging results. Among the medicinal plants, some available plants in our country such as neem, nishinda, tulsi, ashok etc. and spices like garlic, ginger, black cumin etc. are used in poultry 
industries. A great number of plant extracts contain chemical compounds exhibiting antioxidant (Kähkönen et al., 1999) and antimicrobial (Hsieh et al., 2001) properties.

Neem (Azadirachta indica) has a wide range of bioactive components such as azadiractin, nimbin, nimbindin, quercetin and others (Makeri et al., 2007). These components have anti-microbial, anti-fungal, anti-paraparasitic, antioxidants (Elangovan et al., 2000) and have medicinal properties (Bonsu, 2012). Islam et al. (2019) found that addition of neem to the broiler diet positively affects growth parameters and profitability without affecting meat yield, bone development and dressing parameters. Several scientific studies showed that inclusion of neem leaf meal in poultry diet showed significant enhancement in immunity, decreased LDL cholesterol levels and increased body weight gain. Ansari et al. (2012) reported that the neem leaf meal has potentiated immune response in experimental broilers and even the weight of lymphoid organs increased. Neem has been used in animal feed as a growth promoter due to its distinguished antimicrobial capacity as well as its anticoccidial effect in birds (Tipu et al., 2006). Laboni et al. (2007) showed in their experiment that NLM up to $20 \mathrm{~g} / \mathrm{kg}$ dietary level minimizes mortality and morbidity and therefore improves health status of broiler chickens. Chowdhury et al. (2004) reported that both live weight and FCR did not differ significantly when neem leaf meal was used up to $20 \mathrm{~g} / \mathrm{kg}$ dietary level but at $40 \mathrm{~g} / \mathrm{kg}$ level it decreased live weight and increased FCR in broiler chickens. This study has been designed to evaluate the use of neem leaf powder as a potential feed additive in broiler chicken's feed, aiming at improving growth and feed efficiency, ultimately the production of antibiotic free broiler.

\section{Materials and Methods}

\section{Experimental birds, diet and management}

A total of 320 Cobb 500, one-day-old chicks were reared in this experiment. All the chicks were randomly allotted into five equal groups of mixedsex. The chicks were housed in a clean, disinfected and well ventilated room. Diets were formulated based on corn and soybean meal to meet the requirements according to meet nutrient requirements of Cobb-500 commercial broiler
(Cobb Breeder Management Guide, 2012). The dietary treatment groups were; Control (basal diet; no additives), antibiotic (basal diet + antibiotic), NLP-0.25\% (basal diet $+0.25 \%$ neem leaf powder), NLP $0.375 \%$ (basal diet $+0.375 \%$ neem leaf powder) and NLP $0.50 \%$ (basal diet $+0.50 \%$ neem leaf powder). Two types of broiler diets were formulated namely starter and grower (Table 1 ).

Starter diet was provided for the first 21 days and a grower diet was provided to the broiler up to 35 days of age. Fresh neem leaf was collected from neem tree, cleaned, sun-dried and grounded. Trade name of the antibiotics used in the experiment was "Renamycin". Feeds and water were supplied ad-libitum. Prophylactic measures against the most common infectious diseases were carried out. Fresh and dried rice husk was used as litter material. After arrival, the day-old-chicks were placed randomly on the floor of pens. Their initial body weight was recorded just after arrival. For the first few days, feeds were given on a newspaper along with one plastic drinker in each pen. After some days, two round plastic tube feeders and one medium plastic drinker were used.

\section{Data collection and record keeping}

Weekly body weight, body weight gain and feed intake of chicks in different groups were recorded. Feed conversion ratio (FCR) was calculated according to Lambert et al. (1936). At the end of the experiment, one chick from each replication group was randomly selected and slaughtered. After complete bleeding, edible and non-edible byproducts like feather, head, legs, viscera, skin were removed for determination of dressing percentage and carcass weight. Dressed broilers were cut into different major parts such as breast, thigh, drumstick, and wings, and all cutup parts were weighed and recorded. Relative weights of dressing parameters (head, neck, skin and abdominal fat) and internal organs (liver, heart and gizzard) were also determined by calculating the weight of each parameter or organ with respect to body weight. Blood samples were collected from the jugular vein through slaughtering and the samples were centrifuged at $3000 \mathrm{rpm}$ for $10 \mathrm{~min}$ and the serum was stored $-20^{\circ} \mathrm{C}$ until analyzed. The total serum cholesterol, triglyceride and high density lipoproteins (HDL) concentrations were measured according to 
previous methods described by Allain et al. (1974), Bucolo and David (1973) and Alen et al. (1979). Glucose was evaluated using commercial test kit. Serum glutamic-puruvic transaminase (GPT) and glutamic oxaloacetic transaminase (GOT) were determined using methods described by Bahman et al. (2011).

Table 1: Ingredient and nutrient composition of basal diets $(100 \mathrm{~kg})$.

\begin{tabular}{lcc}
\hline Ingredients & $\begin{array}{c}\text { Starter } \\
\text { diet }\end{array}$ & $\begin{array}{c}\text { Grower } \\
\text { diet }\end{array}$ \\
\cline { 2 - 3 } & $\begin{array}{c}\mathbf{( 0 - 2 1} \\
\text { days) }\end{array}$ & $\begin{array}{c}\text { (22-35 } \\
\text { days) }\end{array}$ \\
\hline Maize & 54 & 60 \\
Soybean meal & 30.50 & 24.10 \\
Protein concentrate & 8 & 8 \\
Dicalcium phosphate & 1.35 & 1.35 \\
Limestone & 0.8 & 0.7 \\
Soybean oil & 4.5 & 5 \\
Lysine & 0.10 & 0.1 \\
Methionine & 0.12 & 0.12 \\
Vitamin-mineral premix* & 0.30 & 0.30 \\
Common salt & 0.33 & 0.32
\end{tabular}

\section{Nutrient composition (Calculated)}

Metabolizable

\begin{tabular}{lcc} 
energy $(\mathrm{kcal} / \mathrm{kg})$ & 3113 & 3187 \\
Crude protein \% & 23 & 20.6 \\
Calcium \% & 0.83 & 1.05 \\
Available phosphorus \% & 0.44 & 0.42 \\
Methionine \% & 0.51 & 0.48 \\
Lysine \% & 1.25 & 1.06 \\
\hline
\end{tabular}

*Vitamin mineral premix (Rena-broiler; $2.5 \mathrm{~kg}$ ); Vitamin A $12000000 I U, D 32400000 I U, E 23 g, K 32 g$, $B 12.5 \mathrm{~g}, B 25 \mathrm{~g}, B 64 \mathrm{~g}, B 1212 \mathrm{mg}$, Niacinamide $40 \mathrm{~g}$, $D$ pantothenete $12.5 \mathrm{~g}$, Folate $800 \mathrm{mg}$, Biotin $100 \mathrm{mg}$, Co 400mg, Cu 10g, Fe 60g, I 400mg, Mn 60g, Zn 50g, Se $150 \mathrm{mg}$, Methionine 100g, Lysine 60g, Calcium $679.58 \mathrm{~g}$

\section{Cost of production and profit calculation}

The production cost was calculated including prices of day-old chicks, feeding cost, electricity, heating, medication, management and housing cost at the time of experiment. Selling price was calculated by multiplying total live body weight of the broilers produced by the price per unit weight commonly offered in the market. Some of this cost varies due to fluctuating marketing price. Profit was calculated for both per broiler and per kg broiler by excluding the total cost of production from the total price of birds.

\section{Statistical analysis}

Data of body weight, body weight gain, feed intake, FCR, dressing parameters and serum biochemical parameters of broilers were subjected to analysis of variance in a completely randomized design by using the general linear models of SAS (2009). Duncan's Multiple Range Test was used to compare the differences in mean values. The level of significance was set at $\mathrm{P}<0.05$.

\section{Results}

\section{Growth performances}

Supplementation of NLP showed significant difference in body weight and body weight gain at the end of the experiment (Table 2). At $5^{\text {th }}$ week of age, significantly $(P<0.05)$ higher body weight and body weight gain were found in NLP at $0.25 \%$ and $0.375 \%$ groups as such as antibiotic group compared to the NLP- $0.50 \%$ group. Total feed intake was not differ significantly among the dietary groups $(P>0.5)$. In this study, weekly FCR was not consistent in a regular manner. However, improved $(\mathrm{P}<0.05)$ total FCR was found in NLP$0.25 \%$ group as such antibiotic group compared to the control and NLP-0.50\% groups (Figure 1). Among the NLP supplemented group NLP at $0.25 \%$ and $0.375 \%$ groups performed better.

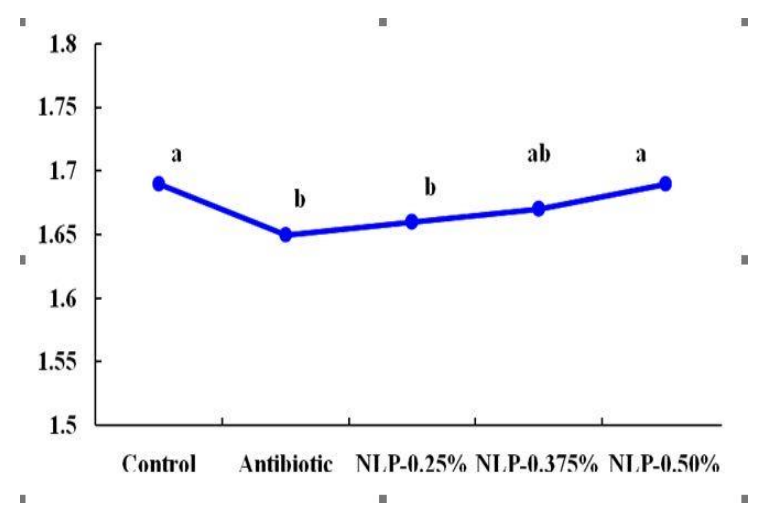

Figure 1: Feed conversion ratio of broiler in different dietary treatments. Within the FCR, different letters indicate significant differences $(P<0.05)$. 


\section{Dressing parameters}

Table 3 shows the dressing percentage and meat yield of different dietary groups. Dressing percentage and meat yields did not show any significant differences $(P>0.5)$ among the dietary groups. Numerically, the highest dressing percentage was found in birds of NLP-0.25\% group. The higher value $(14.48 \%)$ for breast meat and wing meat $(6.44 \%)$ was observed in NLP$0.25 \%$ group. However, highest drumstick $(6.94 \%)$ and thigh meat $(8.28 \%)$ were found in

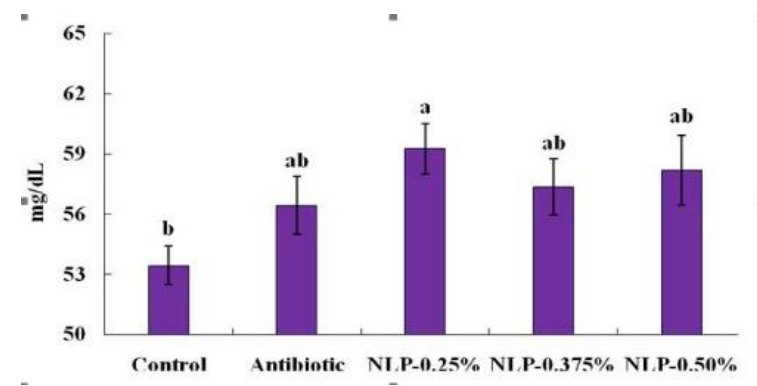

Figure 2: Serum HDL content of broiler in different dietary treatments. Bars not sharing a common letter are significantly different $(P<0.05)$.

Table 2: Body weight, body weight gain and feed intake of broiler in different dietary treatments.

\begin{tabular}{|c|c|c|c|c|c|c|}
\hline \multirow{2}{*}{ Parameter } & \multicolumn{5}{|c|}{ Treatments } & \multirow{2}{*}{$\begin{array}{l}\text { Level of } \\
\text { significan } \\
\text { ce }\end{array}$} \\
\hline & Control & Antibiotic & NLP-0.25\% & NLP-0.375\% & NLP-0.50\% & \\
\hline \multirow{2}{*}{$\begin{array}{l}\text { Final Body } \\
\text { Weight }\end{array}$} & $1346.88^{\mathrm{ab}}$ & $1374^{a}$ & $1363.34^{\mathrm{a}}$ & $1365.78^{\mathrm{a}}$ & $1331.25^{b}$ & \multirow{2}{*}{$*$} \\
\hline & \pm 6.42 & \pm 10.61 & \pm 5.79 & \pm 8.54 & \pm 12.31 & \\
\hline \multirow{2}{*}{$\begin{array}{l}\text { Total Body } \\
\text { Weight Gain }\end{array}$} & $1299.88^{\mathrm{ab}}$ & $1327^{a}$ & $1316.34^{a}$ & $1318.78^{a}$ & $1284.25^{b}$ & \multirow{2}{*}{$*$} \\
\hline & \pm 6.42 & \pm 10.61 & \pm 5.79 & \pm 8.5 & \pm 12.31 & \\
\hline \multirow{2}{*}{$\begin{array}{l}\text { Total Feed } \\
\text { Intake }\end{array}$} & 2198.75 & 2190.25 & 2181 & 2197 & 2164.25 & \multirow{2}{*}{ NS } \\
\hline & \pm 15.32 & \pm 25.12 & \pm 5.80 & \pm 20.04 & \pm 21.99 & \\
\hline
\end{tabular}

* $a, b$ values with different superscripts in the same row differ significantly $(P<0.05)$; Data are presented as mean $\pm S E ; n=320$.

NLP- $0.50 \%$ group. Inclusion of NLP had no significant effect on other dressing parameters (head, neck, liver, gizzard, skin, abdominal fat) in this study.

\section{Serum biochemical parameters}

Serum biochemical parameters of broiler fed different levels of NLP are presented in table 4 and Figure 2. The result indicate that NLP had no effect $(P>0.05)$ on glucose, TG, serum total cholesterol, GPT and GOT. Numerically lower total cholesterol value was found in NLP- $0.25 \%$ group compare to the other groups. Birds fed NLP at $0.25 \%$ showed significantly $(P<0.05)$ higher HDL compared to the control group. HDL in other treatment groups is statistically similar.

\section{Cost-benefit analysis}

Cost-benefit analysis among different dietary treatments is shown in Figure 3. Cost of production per $\mathrm{kg}$ live broiler was numerically higher in control and NLP-0.50\% groups compare to the other groups. Moreover, when live broiler was sold per $\mathrm{kg}$ at equal market price antibiotic group had higher (12.83 tk) profit/kg live bird followed by

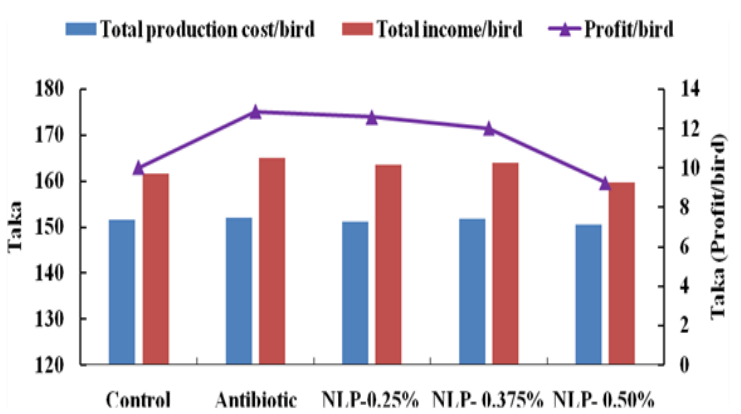

Figure 3: Cost-benefit analysis of broiler in different dietary treatments.

NLP-0.25\% (12.56 tk), NLP-0.375\% (12.00 tk), control (10.01 tk) and NLP-0.50\% (9.24 tk), respectively.

\section{Discussion}

\section{Growth performances}

Supplementation of NLP up to $0.375 \%$ improved body weight as such as antibiotic group than that of control group. A similar result was found by several scientists (Islam et al., 2019; Alam et al., 2015; Ansari et al., 2012) who found significantly higher body weight in neem leaf treated groups 
compared to the control group. Onyimonyi et al. (2009) showed significant improvement in body weight and body weight gain when neem leaves powder were used in broiler diet at a rate of $0.50 \%$. Similarly, Wankar et al. (2009) showed significant improvement in the average of body weight when adding neem leaves powder to broiler diet at a rate of $1,2,3 \mathrm{~g} / \mathrm{kg}$. Sarker et al. (2014) reported that broilers supplemented with $1.0 \%$ neem leaf extract gained significantly higher $(\mathrm{P}<0.001)$ live weight compared to the untreated control group. Ansari et al. (2012) also found diets supplemented with $2.5 \mathrm{~g} / \mathrm{kg}$ of leaf meal had significantly greater body weight than those fed diets with 1.25, $5.0 \mathrm{~g} / \mathrm{kg}$ of leaf meal. These results may be due to neem containing a vast array of chemically diverse and biologically active ingredients (Devakumar and Suktt, 1993) which have antimicrobial and anti-protozoal properties (Kale et al., 2003; Bishnu et al., 2009) that help to reduce the microbial load and improved the growth of the birds (Ketkar, 1976). However, Bonsu et al. (2012) reported that body weight gain was significantly depressed in birds fed by NLM when compared to the control group. Landy et al. (2011) showed a significant decline in the average of body weight when adding powder neem leaves at a rate of 7 and $12 \mathrm{~g} / \mathrm{kg}$ to broiler diet at age

Table 3: Dressing percentage and meat yield of broiler in different dietary treatments (\% relation to body weight).

\begin{tabular}{|c|c|c|c|c|c|c|}
\hline \multirow[t]{2}{*}{ Parameter } & \multicolumn{5}{|c|}{ Treatments } & \multirow{2}{*}{$\begin{array}{l}\text { Level of } \\
\text { significa } \\
\text { nce }\end{array}$} \\
\hline & Control & Antibiotic & NLP-0.25\% & NLP-0.375\% & NLP-0.50\% & \\
\hline $\begin{array}{l}\text { Dressing } \\
\text { percentage }\end{array}$ & $62.36 \pm 1.4$ & $64.52 \pm 2.1$ & $65.29 \pm 1.9$ & $62.18 \pm .9$ & $65.16 \pm 1.6$ & NS \\
\hline $\begin{array}{l}\text { Breast } \\
\text { meat }\end{array}$ & $12.23 \pm 1.63$ & $14.22 \pm 0.97$ & $14.48 \pm 0.56$ & $13.16 \pm 0.94$ & $12.45 \pm 0.90$ & NS \\
\hline Thigh meat & $7.06 \pm 0.06$ & $7.65 \pm 0.19$ & $6.73 \pm 0.34$ & $5.95 \pm 1.0$ & $8.28 \pm 2.46$ & NS \\
\hline $\begin{array}{l}\text { Drumstick } \\
\text { meat }\end{array}$ & $5.89 \pm 0.14$ & $6.43 \pm 0.57$ & $6.24 \pm 0.62$ & $6.57 \pm 0.69$ & $6.94 \pm 1.23$ & NS \\
\hline Wing meat & $4.77 \pm 1.44$ & $5.50 \pm 0.86$ & $6.44 \pm 0.22$ & $6.37 \pm 0.30$ & $6.05 \pm 0.35$ & NS \\
\hline
\end{tabular}

NS, not significant; $n=2$.

Table 4: Blood biochemical parameters of broiler in different dietary treatments.

\begin{tabular}{|c|c|c|c|c|c|c|}
\hline \multirow[b]{2}{*}{ Parameter } & \multicolumn{5}{|c|}{ Treatments } & \multirow{2}{*}{$\begin{array}{l}\text { Level of } \\
\text { significance }\end{array}$} \\
\hline & Control & Antibiotic & $\begin{array}{l}\text { NLP- } \\
0.25 \%\end{array}$ & $\begin{array}{l}\text { NLP- } \\
0.375 \%\end{array}$ & $\begin{array}{l}\text { NLP- } \\
0.50 \%\end{array}$ & \\
\hline \multirow{2}{*}{$\begin{array}{l}\text { Glucose } \\
\text { (mg/dL) }\end{array}$} & 104.55 & 107.43 & 109.95 & 112.13 & 110.20 & \multirow{2}{*}{ NS } \\
\hline & \pm 3.66 & \pm 2.69 & \pm 2.45 & \pm 2.85 & \pm 1.93 & \\
\hline \multirow{2}{*}{$\begin{array}{l}\text { Cholesterol } \\
(\mathrm{mg} / \mathrm{dL})\end{array}$} & 166.32 & 165.26 & 155.27 & 166.18 & 168.18 & \multirow{2}{*}{ NS } \\
\hline & \pm 13.42 & \pm 11.79 & \pm 9.23 & \pm 7.01 & \pm 9.22 & \\
\hline \multirow{2}{*}{$\begin{array}{l}\text { Triglyceride } \\
(\mathrm{mg} / \mathrm{dL})\end{array}$} & 172.93 & 196.97 & 174.81 & 180.14 & 178.58 & \multirow{2}{*}{ NS } \\
\hline & \pm 2.88 & \pm 15.04 & \pm 6.36 & \pm 4.51 & \pm 6.82 & \\
\hline \multirow{2}{*}{ GOT (U/L) } & 3.77 & 4.21 & 3.94 & 4.06 & 4.13 & \multirow{2}{*}{ NS } \\
\hline & \pm 0.16 & \pm 0.16 & \pm 0.28 & \pm 0.36 & \pm 0.31 & \\
\hline \multirow{2}{*}{ GPT (U/L) } & 2.93 & 2.89 & 2.98 & 3.08 & 3.13 & \multirow{2}{*}{ NS } \\
\hline & \pm 0.30 & \pm 0.20 & \pm 0.24 & \pm 0.08 & \pm 0.49 & \\
\hline
\end{tabular}

GOT=Glutamic oxaloacetic transaminase, GPT=Glutamic pyruvic transaminase; NS, Not significant; $n=20$. 
of 42 days, the reason for this may be to bitter taste for neem.

Supplementation of NLP didn't show significant effect on feed intake. These findings is supported by Landy et al. (2011), who found that there were no significant differences between treatments in feed intake when adding a powder neem leaves at a rate of 7 and $12 \mathrm{~g} / \mathrm{kg}$ to broiler diet at age of 42 days. Gowda et al. (1998) reported significantly lower feed intake $(P<0.01)$ for diets with neem kernel meal at 150 and $200 \mathrm{~g} / \mathrm{kg}$ diet in White Leghorns. On the other hand, Shihab (2017) found significant improvement in the feed intake when adding neem leaves powder $(2 \mathrm{~g} / \mathrm{kg})$ to broiler diet. However, no detrimental effect of NLP was found in feed intake of broiler.

Improved total FCR was found in NLP-0.25\% supplemented group in this study. This result agrees with Ansari et al. (2012) who reported that, broiler fed diets supplemented with $2.5 \mathrm{~g} / \mathrm{kg}$ of leaf meal had significantly greater better FCR than those fed diets with $1.25,5.0 \mathrm{~g} / \mathrm{kg}$ of neem leaf meal. Moreover, Sarkar et al. (2021) and Arshad et al. (2021) observed better FCR in neem leaf extract fed broilers and neem leaf powder fed Japanese quail. Kale et al. (2003) reported that antimicrobial and antiprotozoal properties of neem leaves reduced the microbial load of the birds, may absorb more nutrients and thus improved the feed efficiency.

\section{Dressing parameters}

In the present experiment, dressing parameters of broiler chicken were not significantly affected by supplementation of NLP. Some other researchers (Bonsu et al., 2012; Landy et al., 2011) also got the same findings by using neem products that had no significant influence on the dressing percentage of broiler chicken. Dressing percentage was not influenced using NLM at $0 \%, 1.5 \%, 2.0 \%$ and $2.5 \%$ (Bonsu et al., 2012). Ansari et al. (2012) found no marked variation in dressing percentage in the broiler supplementation with NLM at 1.25, 2.5 and $5.0 \mathrm{~g}$ leaf meal $/ \mathrm{kg}$ of feed at 28 days of age. Where, at 42 days of age birds fed with $2.5 \mathrm{~g} / \mathrm{kg}$ of leaf meal showed significantly highest dressing percentage compared to other treatment groups. Alam et al. (2014) also found that polyherbal extract did not exhibit any effect on the dressing percentage values of broiler chicken. The results of the present study were slightly different from the findings of Laboni and Chowdhury (2007) who studied the effects of feeding neem leaf meal on the performance, survival and meat yield characteristics of broilers.

\section{Blood biochemical parameters}

Serum biochemical parameters of broiler fed different levels of NLP are presented in Table 4 and Figure 2. Serum cholesterol in NLP-fed broilers was numerically lower than those of the control birds. This finding agree with Ogbuewu et al. (2011), Uko et al. (2006) and Bonsu et al. (2012), Shihab et al. (2017) who reported hypocholesteromic effects of NLP in rabbits and broilers respectively. Values obtained in this study showed no detrimental effect to the broiler. Inclusion of NLP at $0.25 \%$ increased serum HDL level in this study. This result coincide with Sonhafouo et al. (2019), who observed numerically higher HDL value when graded levels of neem oil was used in broiler diet. HDL is called good cholesterol which has high antioxidant and anti-inflammatory activities that are associated with protection from cardiovascular disease. Liver functioning, the activities of GOT and GPT in serum were not affected significantly by inclusion of neem in broiler diet. However, Ansari et al. (2012) reported decreasing of the same parameters in birds fed on neem leaf meal. Neem and its products contain a hepatoprotective agent and this protective activity may be due to its antioxidant and normalization of impaired membrane function activity (Mohamed et al., 2010).

\section{Cost-benefit analysis}

Higher profitability was found in NLP- $0.25 \%$ group and antibiotic group when all the birds were sold at market price. These findings is supported by Mostofa et al. (2013), who reported that neem leave extract supplementation in the broiler rations may be useful for the safe, economical and efficient production of broiler. However, people now a day are searching for safe, organic, antibiotic residue free food. They will pay extra if the product is antibiotic free. In that case, profitability in neem group will be higher compared to the antibiotic group.

\section{Conclusion}

Supplementation of neem leaf meal powder to the broiler diet positively affects growth performance, feed conversion ratio and serum HDL level. Neem leaf powder up to $0.375 \%$ showed better performances as such as antibiotic fed group. Moreover, higher profitability was found in lower 
level of NLP and antibiotic group when all the birds were sold at market price. Therefore, it can be suggested that neem leaf powder is a potential feed additive and can be added to broiler diet up to $0.375 \%$ for the production of safe broiler meat.

Acknowledgement: This research is funded by Bangladesh Agricultural University Research System (BAURES), Mymensingh.

Conflict of interest: The authors would like to declare that there is no conflict of interest.

\section{References}

Alam MN, J Uddin, MTD Akter, MIZ Moni, F Alom, A Rahman, MA Al Noman (2014). Broiler production by using polyherbal medication (Neem, Nishyinda, Tulsi and Turmeric Extract). International Journal of Innovation and Applied Studies 9(3): 1161-1175.

Alam MM, AT Rakib, MAA Hasan, MS Hasan, MA Ali (2015). Effect of neem (Azadirachta indica) leaf powder supplementation on growth in broilers. International Journal of Natural and Social Sciences 2:22-26.

Allain CC, LS Poon, CSG Chan, W Richmond, PC Fu (1974). Enzymatic determination of total serum cholesterol. Clinical Chemistry 20: 470475.

Allen JK, WJ Hensley, AV Nicholls, JB Whitefield (1979). An enzyme method for estimation high-density lipoprotein cholesterol. Clinical Chemistry 25: 325-327.

Ansari J, SH Khan, A Haq, M Yousuf (2012). Effect of the levels of Azadirachta indica dried leaf meal as phytogenic feed additive on the growth performance and haematobiochemical parameters in broiler chicks. Journal of Applied Animal Research 40(4): 336-345.

Bahman AH, T Alireza, AR Siamak (2011). Comparative study on blood profiles of indigenous and Ross-308 broiler breeders. Global Veterinaria 7: 238-241.

Bishnu J, S Lekhak and A Sharma (2009). Antibacterial property of different medicinal plants: Ocimum sanctum, Cinnamomum zeylanicum, Xanthoxylum armatum and Origanumm ajorana. Kathmandu University
Journal of Science, Engineering and Technology 5: 143-150.

Bonsu FRK, JK Kagya-Agyemang, WKJ Kwenin and HK Zanu (2012). Medicinal response of broiler chickens to diets containing neem (Azadirachta indica) leaf meal, haematology and meat sensory analysis. World Applied Sciences Journal 19(6): 800-805.

Bucolo G, H David (1973). Quantitative determination of serum triglycerides by the use of enzymes. Clinical Chemistry 19: 476482.

Chowdhury SD, BC Datta, ABMS Rahman and SU Ahmed (2004). Efficacy of neem (Azadirachta indica) leaf meal used alone or in combination with a probiotic in the diet of broiler chicks. In: Proceedings of 11th Animal Science Congress. Asian-Australasian Associations of Animal production Societies, Kuala Lumpur, Malaysia.244-247.

Cobb Breeder Management Guide. 2012. Available via https://www.cobb-vantress.com

Devakumar C and DV Suktt (1993). Chemistry, In: Randhawa NS \&Parmar BS (eds), Neem research and development. pp. 63-96.

Elangovan AV, SVS Verna and VRB Sastrry (2000). Effect of feeding neem (Azadirachta indica) leaf meal on growth and nutrient utilization. CAB International, Welling Ford, UK, p: 95.

El-Latif ASA, NS Saleh, TS Allam and EW Ghazy (2013). The effects of rosemary (Rosemarinus officinalis) and garlic (Allium sativum) essential oils on performance, hematological, biochemical and immunological parameters of broiler chickens. Brazilian Journal of Poultry Science 2: 16-24.

FAO, 2003. OIE/WHO Expert workshop on nonhuman antimicrobial usage and antimicrobial resistance: First Work shop on Scientific Assessment, 1-5 December 2003, Geneva, World Health Organization.

Gowda SK, SV Verma, AV Elangovan, SD Singh (1998). Neem (Azadirachta indica) kernel meal in the diet of White Leghorn layers. British Poultry Science 39(5): 648-652.

Hasan MM, ME Hossain, MAK Azad, MM Hossain and AS Afsana (2018). Comparison of green tea and probiotic as alternatives to antibiotic 
growth promoter in broiler ration. The Bangladesh Veterinarian 35(1 \& 2): 13- 24.

Hossain ME, CJ Yang (2014). Effect of fermented water plantain on growth performance, meat composition, oxidative stability, and fatty acid composition of broiler. Livestock Science. 162: 168-177.

Hossain ME, SY Ko, GM Kim, JD Firman, CJ Yang (2012). Evaluation of probiotic strains for development of fermented Alisma canaliculatum and their effects on broiler chickens. Poultry Science. 91: 3121-3131.

Hsieh PC, JL Mau, SH Huang (2001) Antimicrobial effect of various combinations of plant extracts. Food Microbiology 18(1): 35-43.

Islam KMS, H Schaeublin, C Wenk, M Wanner, A Liesegang (2012). Effect of dietary citric acid on the performance and mineral metabolism of broiler. Journal of Animal Physiology and Animal Nutrition 96: 808-817.

Islam R, MM Hossain, F Nargis and ME Hossain (2019). Administration of garlic and neem in broiler diet for safe meat production. Bangladesh Journal of Animal Science, 48 (2):116-126.

Kähkönen MP, AI Hopia, HJ Vuorela, JP Rauha, K Pihlaja, TS Kujala and M Heinonen (1999). Antioxidant activity of plant extracts containing phenolic compounds. Journal of Agricultural and Food Chemistry 47(10): 3954-3962.

Kale BP, MA Kothekar, HP Tayade, JB Jaju, M Mateenuddin (2003). Effect of aqueous extract of Azadirachta indica leaves on hepatotoxicity induced by antitubercular drugs in rats. Indian Journal of Pharmacology 35: 177-180.

Ketkar CM (1976). Utilization of neem (Azadirachta indica Juss.) and its byproducts. Final technical report of directorate of non-edible oils and soap industry, khadi and village industries commission. Published by $\mathrm{V}$. Lahshmikanthan, Irla Road, Vile Parle, Bombay 400056.

Kharde KR, S Soujanya (2014). Effect of garlic and neem leaf powder supplementation on growth performance and carcass traits in broilers. Veterinary World 7(10): 799-802.
Laboni S and SD Chowdhury (2007). Efficacy of neem (Azadirachtaindica) leaf meal as a dietary additive in commercial broiler chickens. Bangladesh Veterinarian 24(2): 120-129.

Lambert WV, NR Ellis, WH Block and HW Titus (1936). The role of nutrition in genetics. American Research Society of Animal Production 29: 236.

Landy N, GH Ghalamkari, M Toghyani (2011). Performance, carcass characteristics and immunity in broiler chickens fed dietary Neem (Azadirachta indica) as alternative for an antibiotic growth promoter. Livestock Science 142: 305-309.

Lu L and WA Walker (2001). Pathologic and physiologic interactions of bacteria with the gastrointestinal epithelium. American Journal of clinical Nutrition 73: 1124S-1130S.

Makeri HK,VA Maikai and JA Nok (2007). Effect of tropical application of neem seed (Azadirachta indica) extract on sheep infested with Amblyomma variegatum. African Journal of Biotechnology 6(20): 2324-2327.

Mohamed ET, AM Hisham and SM Marwa (2010). Hepato ameliorative effect of Azadirachta indica leaves extract against mercuric chloride environmental pollution. Journal of American Science 6:735-751.

Mostofa M, S Khatun, F Alom, J Uddin, MN Alam and NF Moitry (2013). Efficacy of tulsi and neem leaves extract in broiler production. Bangladesh Journal of Veterinary Medicine 11(1): 1-5.

Ogbuewu IP, VU Odoemenam, HO Obikaonu, MN Opara, OO Emenalom, MC Uchegbu, IC Okoli, BO Esonu and MU Iloje (2011). The growing importance of neem (Azadirachta indica) in agriculture, industry, medicine and environment: A Review. Research Journal of Medicinal Plants 5(3): 230-245

Onyimonyi AE, A Olabode, GC Okeke (2009). Performance and economic characteristics of broilers fed varying dietary levels of neem leaf meal (Azadirachta indica). International Journal of Poultry Science 8(3): 256-259.

Rashid MH, SC Das, MM Hossain, ME Hossain (2020). Effects of garlic and green tea as 
alternative feed additives in broiler diet. Journal of Bangladesh Agricultural University 18(4): 1013-1020.

Sarkar S, M Tarafder, MH Rahman, M Khandaker, GS Ahammad, DK Sarker, BC Karmakar, B Islam (2021). Dietary supplementation effects of the levels of Neem (Azadirachta indica) leaf extracts as phytogenic feed additive on the growth performance in broiler chicks. Asian Journal of Medical and Biological Research 7 (1): 64-68.

Sarker SK, M Mostofa, F Akter, MM Rahman and MR Sultana (2014). Effects of aqueous extract of neem (Azadirachta indica) leaves as growth promoter and anti colibacillosis in broilers. Bangladesh Journal Animal Science 43(2): 138- 141

SAS (2009). SAS User's Guide, Version 9.1 edn. SAS Institute, Cary, NC.

Shihab IM (2017). Impact of supplementation neem powder (Azadirachta indica) to diet broiler in immunological, physiological and productive traits. Advances in Environmental Biology. 11: 44-51.
Shihab IM, TBM AL-Zuhariy, SM Abdullah, SS Mutar (2017). Impact of supplementation Neem powder (Azadirachta indica) to diet broiler in immunological, physiological and productive traits. Advances in Environmental Biology 11(3): 44-51.

Sonhafouo VM, JR Kana, KN Dongmo (2019). Effects of graded levels of Azadirachta indica seed oil on growth performance and biochemical profiles of broiler chickens. Veterinary Medicine and Science 5(3): 442450.

Stanton TB (2013). A call for antibiotic alternatives research. Trends in Microbiology 21(3): 111113.

Tipu MA, MS Akhtar and ML Raj (2006). New dimension of medicinal plants as animal feed. Pakistan veterinary Journal 26(3): 144-148.

Uko OJ, TN Kamalu, UH Pindaga and JS Rabo (2006). Studies on toxicity to cockerel chicks of raw full-fat neem (Azadirachta indica A. Juss) seed kernel. Veterinarski Arhiv 76(2): 135-144.

Wankar AK, RN Shirbhate, KB Bahiram, SA Dherge, RA Jasutkar (2009). Effect of neem (Azadirachta indica) leaf powder supplementation on growth in broilers. Veterinary World 2(10): 396-397. 